\title{
ZASTOSOWANIE INSPEKCJI TERMOWIZYJNEJ DO OCENY POPRAWNOŚCI MONTAŻU POLĄCZEŃ RUROWYCH
}

\begin{abstract}
W pracy przedstawiono metodę kontroli jakości połączeń rur strukturalnych, wykonanych z tworzywa sztucznego, z kielichami. Połączenie to jest realizowane metodą zgrzewania tarciowego. Do oceny poprawności montażu połączeń rurowych zastosowano inspekcję termowizyjną polegającą na analizie rozkładu temperatur na powierzchni materiału. Przed operacją zgrzewania wykonano symulowane wady w postaci uszkodzeń karbów rury. W celu sprawdzenia czułości metody wykonano cztery wady różniące się powierzchnią i głębokością uszkodzeń. Badania eksperymentalne przeprowadzono bezpośrednio $\mathrm{w}$ zakładzie produkcyjnym z zastosowaniem metody termografii pasywnej, jak również w warunkach laboratoryjnych za pomocą metody termografii aktywnej. W metodzie termografii pasywnej energia cieplna pochodzi wyłącznie $z$ badanego obiektu, bez dodatkowej stymulacji zewnętrznym źródłem energii. W tym przypadku jest wykorzystywane ciepło pozostałe po procesie formowania rury oraz dodatkowo ciepło wygenerowane W procesie zgrzewania. W metodzie termografii aktywnej jest analizowana odpowiedź materiału na stymulację zewnętrznym źródłem energii. Głównym elementem systemu inspekcji jest kamera termowizyjna wyposażona w niechłodzony sensor mikrobolometryczny pracujący w długofalowym zakresie promieniowania podczerwonego. Podczas badań rura była obracana względem kamery IR w celu umożliwienia kontroli obszaru połączenia na całym obwodzie. Na zarejestrowanych termogramach obserwowano zmianę temperatury w obszarze uszkodzeń poprzez analizę rozkładu temperatur wzdłuż wybranych profili. Na potrzeby badań laboratoryjnych utworzono stanowisko eksperymentalne z napędem elektrycznym, umożliwiające precyzyjny obrót fragmentu rury z wykonaną zgrzeiną względem kamery termowizyjnej.
\end{abstract}

Słowa kluczowe: pasywna i aktywna termografia, detekcja wad, zgrzewanie tarciowe

\footnotetext{
${ }^{1}$ Autor do korespondencji, coresponding author: Piotr Czajka, Instytut Technologii Eksploatacji - Państwowy Instytut Badawczy, ul. Pułaskiego 6/10, 26-600 Radom.

2 Jordan Mężyk, Instytut Technologii Eksploatacji - Państwowy Instytut Badawczy, ul. Pułaskiego 6/10, 26-600 Radom.

${ }^{3}$ Wojciech Mizak, Instytut Technologii Eksploatacji - Państwowy Instytut Badawczy, ul. Pułaskiego 6/10, 26-600 Radom.
} 


\section{Wprowadzenie}

Celem badań jest inspekcja połączeń rur z kielichami, które to są realizowane metodą zgrzewania tarciowego. Według producenta metoda zapewnia dużą stabilność połączenia oraz wysoką szczelność w porównaniu z rurami bezkielichowymi, tzw. bosymi łączonymi za pomocą kształtek dwukielichowych. $\mathrm{Na}$ rysunku 1. przedstawiono przekrój poprzeczny modelu rury połączonej z kielichem. Obszar zgrzeiny obejmuje dwa karby rury. Metoda zgrzewania tarciowego należy do kategorii połączeń nierozłącznych.

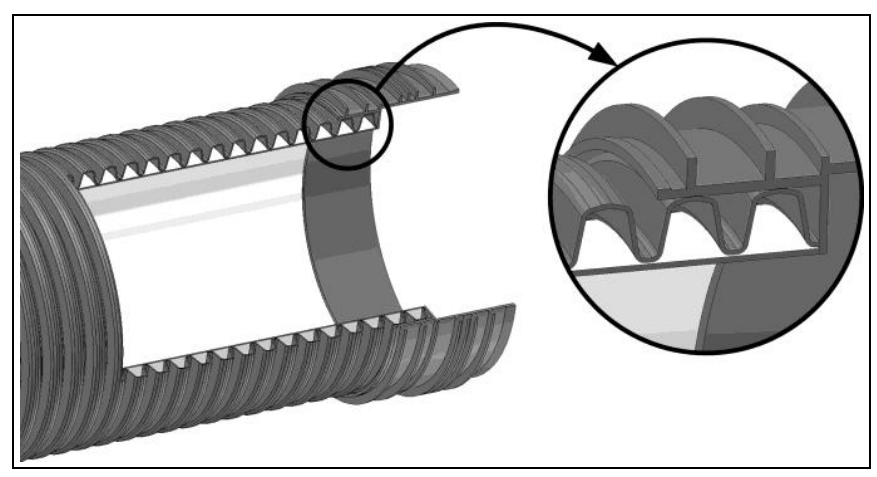

Rys. 1. Prezentacja obszaru połączenia rury karbowanej z kielichem

Fig. 1. Presentation of the joint area of the crimp pipe with faucet

Do kontroli jakości połączeń rur z kielichami zaproponowano metodę termowizyjna, polegającą na pomiarze promieniowania cieplnego wysyłanego przez obiekt $\mathrm{i}$ wyznaczaniu na tej podstawie rozkładu temperatury na jego powierzchni. Umożliwia to monitorowanie temperatury obiektów, a także wykrywanie defektów powierzchniowych i podpowierzchniowych w materiałach [1-7]. Zaletą stosowania metod wizyjnych jest bezkontaktowy oraz nieniszczący charakter badań (ang. non-destructive testing - NDT), co pozwala na wykrywanie wad bez obniżania parametrów badanego wyrobu $[1,3,5,7]$.

Inspekcja $\mathrm{w}$ podczerwieni może być realizowana $\mathrm{z}$ zastosowaniem tzw. termografii pasywnej (ang. passive infrared thermography) lub termografii aktywnej (ang. active infrared thermography) [2-6]. W pierwszej metodzie jest wykorzystywane ciepło emitowane przez badany obiekt, który został „naturalnie" ogrzany w wyniku poddawania go różnym procesom technologicznym (tak jak podczas formowania elementów z tworzywa) lub w wyniku pracy obiektu (tak jak np. w przypadku elementów elektronicznych). W drugiej metodzie podczas prowadzenia badań obiekt jest ogrzewany „sztucznie” zewnętrznym źródłem energii, np. za pomocą lampy halogenowej, lasera, ultradźwięków lub promienników podczerwieni. W obu przypadkach temperatura obserwowanego obiektu powinna różnić się znacząco od temperatury otoczenia, tak aby była 
możliwa obserwacja zachodzących zjawisk za pomocą kamery termowizyjnej. Wykrywanie defektów podpowierzchniowych jest możliwe, kiedy mają one inne właściwości termiczne niż badany obiekt. Energia cieplna dyfunduje wewnątrz materiału z szybkością zależną od jego właściwości; natrafiając na defekt, powoduje zmianę szybkości tej dyfuzji, która objawia się zmianą temperatury na powierzchni obiektu [1, 3, 5-7]. W przypadku propagacji energii cieplnej od powierzchni w głąb materiału defekt zmniejszający szybkość dyfuzji w stosunku do otaczającego materiału ujawni się w postaci lokalnego wzrostu temperatury na powierzchni, natomiast defekt zwiększający szybkość dyfuzji - w postaci lokalnego spadku temperatury $[3,5,6]$. W przypadku propagacji ciepła z głębi materiału na powierzchnię przedstawione zależności są odwrotne.

$\mathrm{W}$ opisywanych badaniach zastosowano zarówno metodę termografii pasywnej, jak i termografii aktywnej. W pomiarach wykonanych u producenta wykorzystano energię cieplną pozostała po uformowaniu rury w korugatorze, natomiast $\mathrm{w}$ testach prowadzonych $\mathrm{w}$ laboratorium rurę ogrzewano od strony wewnętrznej, jak i zewnętrznej za pomocą promienników podczerwieni, uzyskując różne konfiguracje układów pomiarowych. Pozwoliło to na identyfikację symulowanych wad w zgrzewanym połączeniu rury z kielichem.

\section{Badania eksperymentalne w zakładzie produkcyjnym}

W przypadku badań in situ przedmiotem eksperymentów były rury o średnicy zewnętrznej $600 \mathrm{~mm}$ z zamontowanym kielichem, pochodzące z linii produkcyjnej. Rura po wyjściu z korugatora ma temperaturę około $60^{\circ} \mathrm{C}$. Po zakielichowaniu i przetransportowaniu do stanowiska paletyzacji, na którym wykonano pomiary, powierzchnia zewnętrzna rury jest ochłodzona do około $40^{\circ} \mathrm{C}$, podczas gdy powierzchnia pomiędzy karbami $\mathrm{w}$ dalszym ciagu utrzymuje temperaturę około $60^{\circ} \mathrm{C}$. Do realizacji badań eksperymentalnych zastosowano kamerę termowizyjną z niechłodzonym sensorem mikrobolometrycznym o rozdzielczości 640 x 480 pikseli. Sensor kamery pracuje w długofalowym zakresie promieniowania podczerwonego $7,5 \div 14 \mu \mathrm{m}[5,6,8]$. Początkowo kamera została ustawiona tak, aby monitorować bezpośrednio proces zgrzewania tarciowego (rys. 2a). W procesie tym rura jest unieruchamiana, a kielich wprowadzany w ruch obrotowy. Następnie obracający się kielich jest nasuwany na rurę. $\mathrm{W}$ trzecim etapie następuje zwolnienie kielicha $\mathrm{z}$ uchwytu wrzeciona oraz wycofanie podpór i wrzeciona.

$\mathrm{Na}$ termogramie (rys. 2b) jest widoczny duży kontrast temperaturowy pomiędzy kielichem pozostającym $\mathrm{w}$ temperaturze otoczenia a rurą emitująca energię cieplną pozostałą po procesie formowania. W wyniku procesu zgrzewania tarciowego jest generowana dodatkowa energia cieplna, która jest rejestrowana na termogramie $\mathrm{w}$ postaci lokalnego wzrostu temperatury na styku rury z kielichem. Ze względu na niską przewodność cieplną tworzywa sztucznego bezpośrednio po procesie zgrzewania zewnętrzna powierzchnia kielicha $\mathrm{w}$ ob- 
szarze zgrzeiny nie wykazuje kontrastu temperaturowego względem pozostałych obszarów kielicha. Następnie kamera termowizyjna została ustawiona w rejonie pola odkładczego celem obserwacji procesów cieplnych zachodzących w rurze i kielichu podczas swobodnego chłodzenia. Początkowo kielich pozostawał zimny, lecz w miarę upływu czasu jego część mająca kontakt z rurą ogrzewała się, co pozwoliło na obserwację wykonanej zgrzeiny za pomocą kamery termowizyjnej. Po upływie około 5 min od momentu wykonania zgrzewania tarciowego na powierzchni kielicha ujawnia się lokalny wzrost temperatury w obszarze zgrzeiny (rys. 3.), obejmujący dwa karby rury.
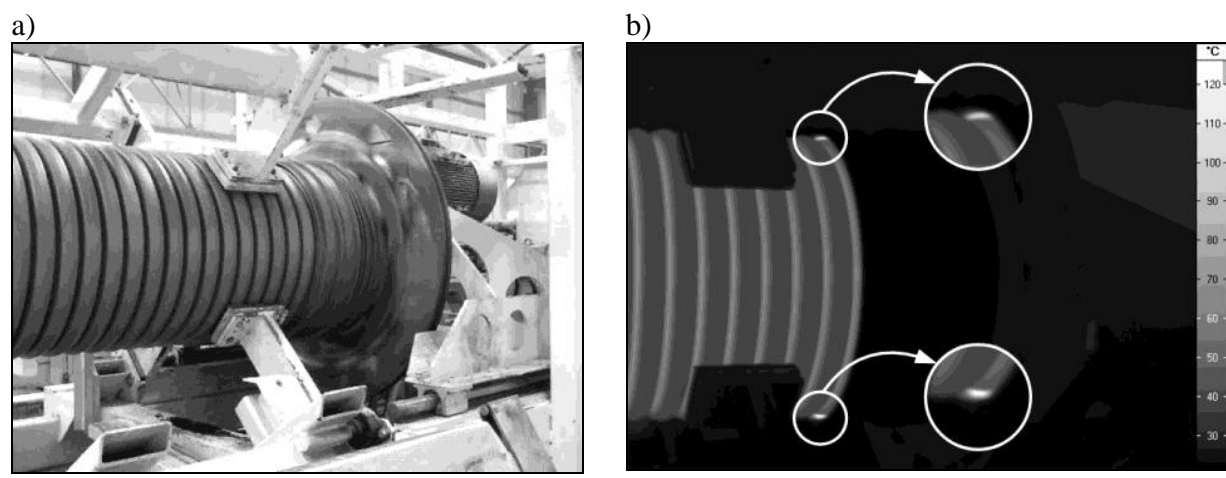

Rys. 2. Proces zgrzewania tarciowego: a) fotografia w paśmie widzialnym, b) termogram w podczerwieni

Fig. 2. Friction welding process: a) photography in the visible band, b) infrared photography

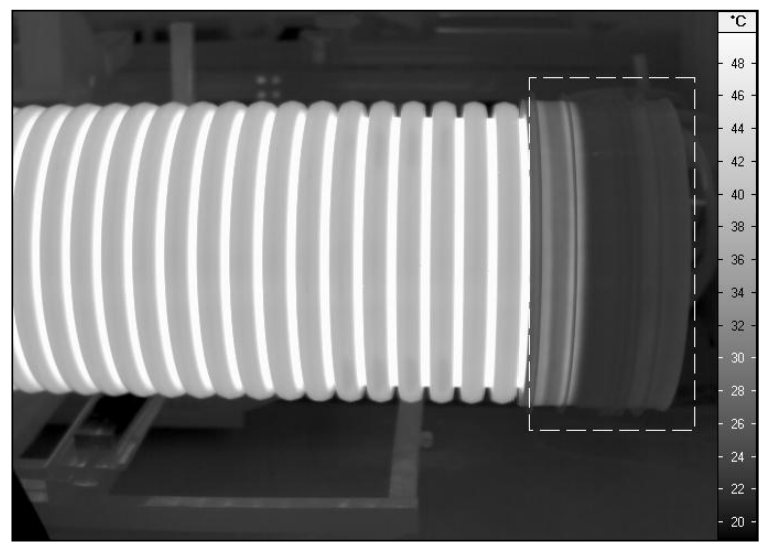

Rys. 3. Obraz termowizyjny rury z kielichem uzyskany po upływie około 5 minut od momentu wykonania zgrzewania

Fig. 3. Thermovision image of the pipe with the faucet obtained about 5 minutes after welding

Po przeprowadzeniu wstępnych badań, których celem było ustalenie warunków pomiaru, przed operacją zgrzewania wykonano symulowane wady w postaci uszkodzeń karbów rury. W celu sprawdzenia czułości metody wykonano cztery wady różniące się powierzchnią i głębokością uszkodzeń (rys. 4.). 
Wada nr 1 (rys. 4a) charakteryzuje się uszkodzeniem karbu rury na dużym obszarze i głębokości. Wymiary powierzchniowe defektu wynoszą ok. $127 \mathrm{x}$ $40 \mathrm{~mm}$. Wada nr 2 (rys. 4b) to rozległe powierzchniowe uszkodzenie karbów. Przybliżone wymiary większego defektu wynoszą 140 x $20 \mathrm{~mm}$. Wada $\mathrm{nr} 3$ (rys. 4c) polega na wykonanym przecięciu poprzecznym karbu rury. Powstała szczelina ma szerokość około $3 \mathrm{~mm}$, natomiast całkowity wymiar powierzchni uszkodzenia wynosi 23 x $50 \mathrm{~mm}$. Wada $\mathrm{nr} 4$ (rys. 4d) to małe uszkodzenie powierzchniowe o wymiarach około $8 \times 23 \mathrm{~mm}$. Rzeczywiste wady pojawiają się w sposób losowy i występują głównie w przypadku, gdy rura i kielich pochodzą ze skrajnych zakresów tolerancji. Powstające wady wpływają negatywnie na wytrzymałość mechaniczną połączenia, brak jest jednak informacji o częstotliwości występowania tego typu defektów.

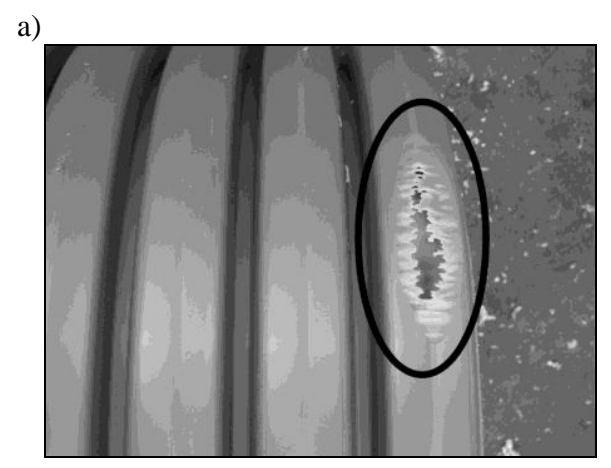

c)

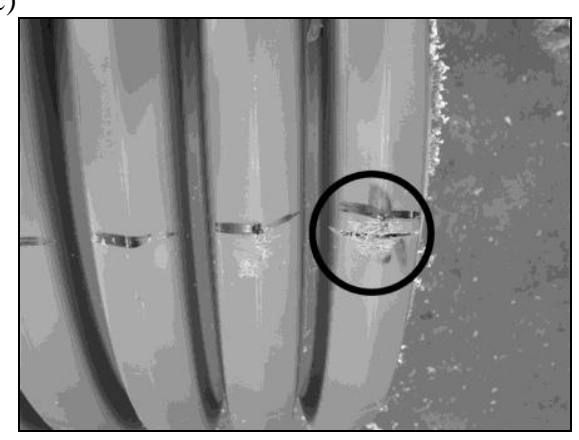

b)

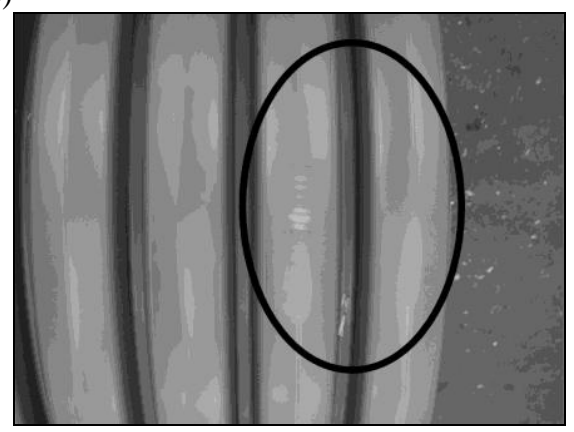

d)

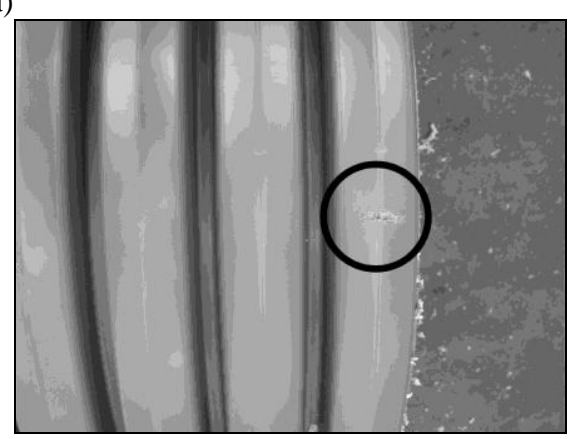

Rys. 4. Symulowane wady wykonane przed operacją zgrzewania: a) wada nr 1 (rozległa, głęboka), b) wada nr 2 (rozległa, powierzchniowa), c) wada nr 3 (przecięcie), d) wada nr 4 (małe uszkodzenie)

Fig. 4. Simulated defects made before welding operation: a) defect no. 1 (extensive, deep), b) defect no. 2 (extensive, superficial), c) defect no. 3 (cut), d) defect no. 4 (little damage)

Następnie po wykonaniu zgrzeiny zarejestrowano serię obrazów termowizyjnych obszaru połączenia. Kamera IR została ustawiona na statywie nad rurą i skierowana pionowo w dół. Rura była obracana względem kamery termowi- 
zyjnej w celu umożliwienia kontroli obszaru połączenia na całym obwodzie. Na tym etapie badań eksperymentalnych obrót był realizowany w sposób niezautomatyzowany. Na termogramach zaobserwowano zmianę temperatury w obszarze uszkodzeń nr 1, 2 i 3 (rys. 5.). Nie udało się natomiast zlokalizować najmniejszego uszkodzenia (wada $\mathrm{nr}$ 4).

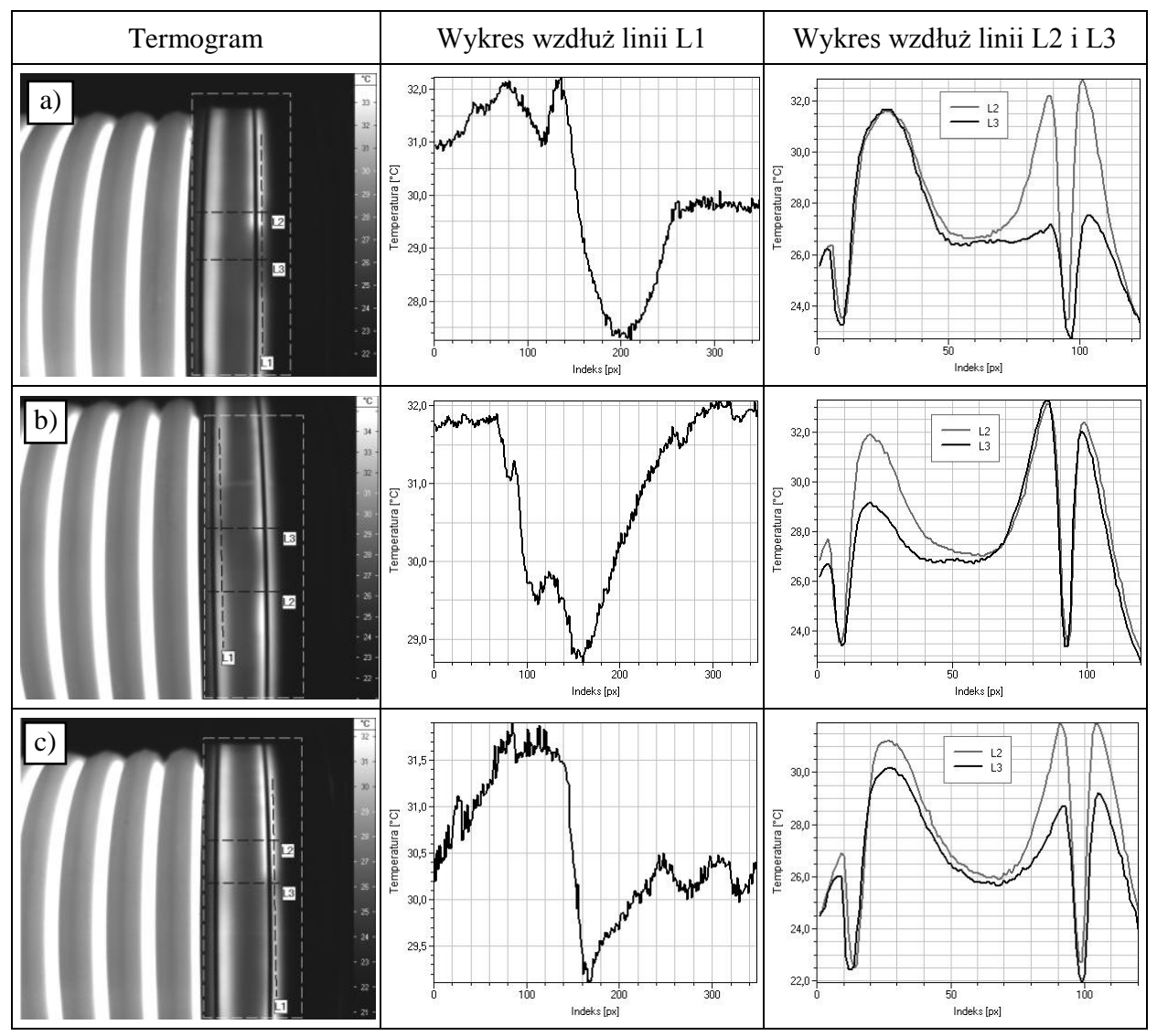

Rys. 5. Uzyskane przykładowe wyniki badań eksperymentalnych w rzeczywistych warunkach pracy: a) wada nr 1 (rozległa, głęboka), b) wada nr 2 (rozległa, powierzchniowa), c) wada $\mathrm{nr} 3$ (przecięcie)

Fig. 5. Examples of experimental tests results determined in real operating conditions: a) defect no. 1 (extensive, deep), b) defect no. 2 (extensive, superficial), c) defect no. 3 (cut)

Przeprowadzono analizę rozkładu temperatur wzdłuż wybranych linii na termogramie. Zaproponowano kierunek analizy wzdłuż zgrzeiny (linia L1) oraz dodatkowo w kierunku prostopadłym (linie L2 i L3). Uzyskane wykresy profili temperaturowych wzdłuż linii L1 wskazują lokalne obniżenie temperatury w obrębie zasymulowanych wad. Występujące defekty mają charakter ubytków 
w materiale w postaci pustych przestrzeni, które powodują brak kontaktu między rurą a kielichem. Utrudnione w tym przypadku przenikanie energii ku powierzchni powoduje powstanie obszarów o niższej temperaturze $[3,5,6]$. W przypadku wykresów profilowych w kierunku prostopadłym do zgrzeiny (wzdłuż linii L2 i L3) długość linii obejmuje dwa karby, które są widoczne w postaci obszarów o wyższej temperaturze. Na zewnątrz kielicha występują kołnierze (rys. 1.), które powodują że rozkład temperatury zgrzewu w tym obszarze jest zaburzony (powtarzające się na wykresach obszary o niższej temperaturze). Obszarów tych nie należy uwzględniać w analizie. Wykresy wzdłuż linii L2 zostały wykonane dla fragmentów niewykazujących wad, natomiast wykresy wzdłuż linii L3 prezentują rozkład temperatury w obrębie defektów. Porównując oba wykresy, jest widoczne lokalne obniżenie temperatury uszkodzonych obszarów.

Po wykonaniu przedstawionego eksperymentu stwierdzono, że konieczne jest zapewnienie stabilnego obrotu rury względem systemu wizyjnego. Kielich $\mathrm{z}$ fragmentem rury zawierającym wady połączenia został przekazany przez producenta do przeprowadzenia dalszych badań w Instytucie Technologii Eksploatacji PIB.

\section{Badania w warunkach laboratoryjnych}

Badania laboratoryjne wykonano na opracowanym stanowisku eksperymentalnym pozwalającym na pomiary z wykorzystaniem metody termografii aktywnej (rys. 6.). Konstrukcja stanowiska pozwala na ogrzewanie, za pomoca promienników podczerwieni, zarówno wewnętrznej, jak i zewnętrznej powierzchni rury. Moduł promiennika IR zawiera dwie lampy podczerwieni, każda o mocy jednostkowej $500 \mathrm{~W}$ [6]. Odpowiedź obiektu na pobudzenie cieplne może być rejestrowana bezpośrednio na pobudzanej powierzchni (przednia projekcja, ang. forward projection) lub też na powierzchni przeciwnej, po przejściu fali cieplnej przez obiekt (projekcja tylna, ang. back projection) $[5,7]$. W celu zapewnienia precyzyjnego obrotu fragmentu rury z kielichem została opracowana konstrukcja stanowiska, w skład której wchodzi: rama nośna, zestaw czterech rolek podpierających, dwa zestawy rolek prowadzących, serwonapęd (rys. 7.).

Rama jest wykonana z profili aluminiowych, zapewniających małą masę oraz dużą sztywność całego układu. Dodatkową zaletą takiego rozwiązania jest łatwa rekonfiguracja stanowiska. Badany fragment rury z kielichem jest posadowiony na rolkach podpierających, które ustalają jej pozycję względem płaszczyzny XZ oraz umożliwiają obrót względem własnej osi. Rolki pozycjonujące $\mathrm{z}$ dwóch stron stycznie przylegają do kołnierza na kielichu, przez co ograniczaja możliwości przemieszczania się rury względem osi X. Rozwiązanie takie pozwala precyzyjnie pozycjonować badany obiekt, co umożliwia uzyskanie stabilnego obrazu $\mathrm{z}$ kamery termowizyjnej. Moduł napędu jest posadowiony na wsporniku, który umożliwia pozycjonowanie wzdłuż osi X oraz Z. Na wałku 
przekładni jest osadzona rolka napędowa, której powierzchnia zewnętrzna stycznie współpracuje z powierzchnią wewnętrzną kielicha, dzięki czemu ruch obrotowy z przekładni jest przekazywany na badany obiekt. Powierzchnia zewnętrzna rolki napędowej w celu zwiększenia siły tarcia oraz zabezpieczenia rolki przed zjawiskiem poślizgu została poddana procesowi radełkowania. Przed przystąpieniem do badania napęd jest przesuwany w skrajne prawe położenie wzdłuż osi X, co umożliwia łatwe osadzenie rury na rolkach, następnie po ustaleniu pozycji rury napęd jest przesuwany w skrajne lewe położenie. W dalszej kolejności moduł napędu jest przemieszczany wzdłuż osi $\mathrm{Z}$ do momentu uzyskania styku rolki napędowej z powierzchnią wewnętrzną kielicha, po czym jego pozycja jest ustalana za pomocą śrub dociskowych. Układ sterowania umożliwia płynną regulację prędkości obrotowej badanego obiektu. Dla rury o średnicy zewnętrznej $600 \mathrm{~mm}$ uzyskano możliwość zmiany prędkości obrotowej rury w zakresie $0 \div 6 \mathrm{obr} / \mathrm{min}$. Konstrukcja ramy umożliwia przeprowadzanie pomiarów w warunkach laboratoryjnych dla fragmentów rur o średnicy $150 \div 1000 \mathrm{~mm}$ i długości do $800 \mathrm{~mm}$.
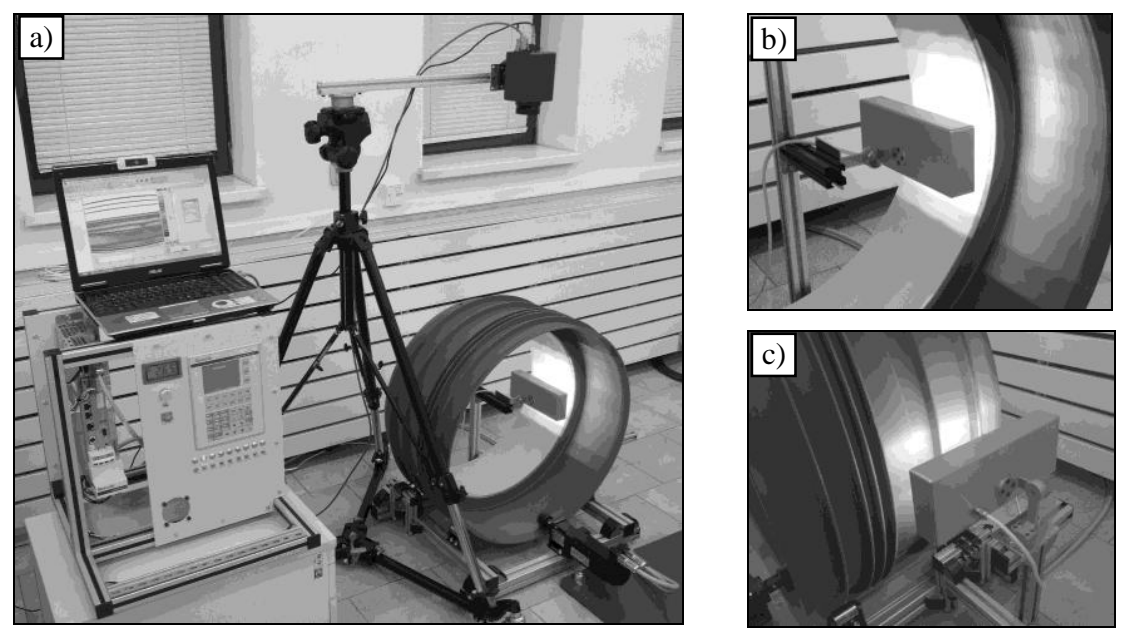

Rys. 6. Eksperymentalne stanowisko badawcze do kontroli jakości połączeń rur z kielichami metodą termografii aktywnej: a) widok ogólny stanowiska, b) promiennik IR do ogrzewania wewnętrznej powierzchni rury, c) promiennik IR do ogrzewania zewnętrznej powierzchni rury

Fig. 6. Experimental test stand for quality inspection of the joint of the pipe with faucets using active termography method: a) general view of the stand, b) IR radiator for heating of inner surface of pipe, c) IR radiator for heating of outer surface of the pipe

Program badań obejmował przeprowadzenie doświadczeń z zastosowaniem projekcji przedniej oraz tylnej. Kielich z fragmentem rury był obracany ze stałą prędkością wokół swojej osi. Kamera termowizyjna była ustawiona tak, że obserwowała powierzchnię zewnętrzną kielicha pionowo od góry, natomiast pro- 
mienniki podczerwieni zamontowano po wewnętrznej i zewnętrznej stronie powierzchni rury. Wykonano eksperymenty z różnymi czasami nagrzewania rury i różnym okresem rejestracji obrazów termowizyjnych. Ostatecznie ustalono czas ogrzewania badanego obiektu równy $10 \mathrm{~min}$, następnie promienniki wyłączano i dokonywano rejestracji termogramów przez kolejne 10 min. Najlepsze wyniki uzyskano podczas rejestracji obrazów natychmiast po wyłączeniu promiennika w przypadku projekcji tylnej i po odczekaniu około 2 min w przypadku projekcji przedniej. Prędkość obrotowa rury podczas badań została ustawiona na $2 \mathrm{obr} / \mathrm{min}$.

Rys. 7. Model stanowiska do obrotu fragmentu rury z kielichem

Fig. 7. Stand model for turn of a fragment of the pipe with faucet

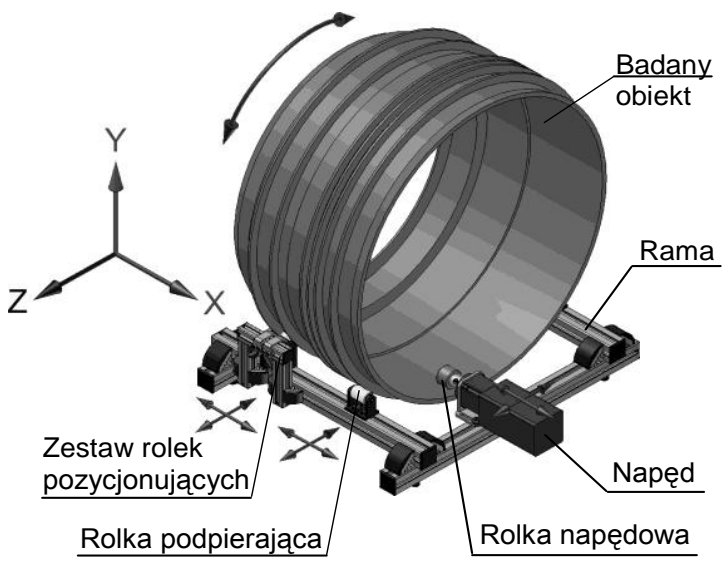

Analizując zarejestrowane sekwencje termogramów, poszukiwano odchyleń temperatury na powierzchni kielicha, a następnie, wykorzystując narzędzia dostępne w oprogramowaniu kamery, wyznaczono profile temperaturowe w wytypowanych obszarach wzdłuż zgrzeiny. Na uzyskanych wykresach pojawiają się wahania temperatury (przykłady na rys. 8. i 9.), wskazujące na występujące pod powierzchnią anomalie w postaci defektów. Analizy te pozwoliły na jednoznaczne wykrycie wad nr 1 i 3 . Wada nr 4 pozostała niewidoczna, podobnie jak w badaniach w zakładzie produkcyjnym, natomiast wada nr 2 ujawniała się jedynie $\mathrm{w}$ postaci niewielkich odchyłek temperatury na poziomie szumu pomiarowego, co nie pozwoliło na jednoznaczną jej identyfikację zastosowaną metodą. W przypadku projekcji przedniej można zaobserwować, że na powierzchni kielicha występują obszary o podwyższonej temperaturze w miejscu występowania defektów (rys. 8.).

Energia cieplna wygenerowana za pomocą promienników IR wnika w głąb materiału. W miejscu, gdzie fala cieplna napotyka defekt o mniejszej przewodności temperaturowej niż otaczający go materiał, następuje akumulacja energii i w konsekwencji utrzymanie temperatury danego obszaru, podczas gdy materiał wokół obniża swoją temperaturę, ponieważ energia cieplna przenika w głębsze warstwy materiału $[3,5,6]$. 


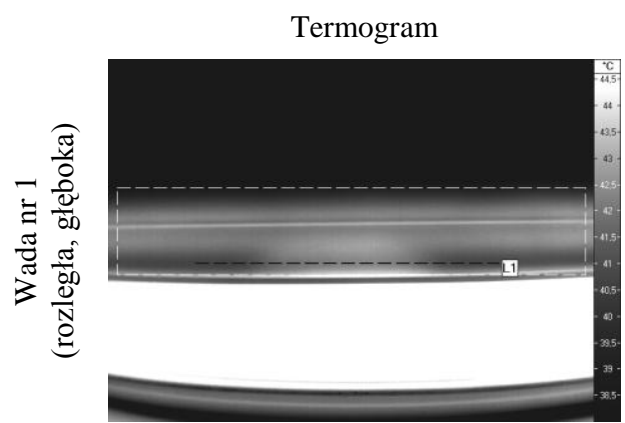

Wykres wzdłuż linii L1 na termogramie
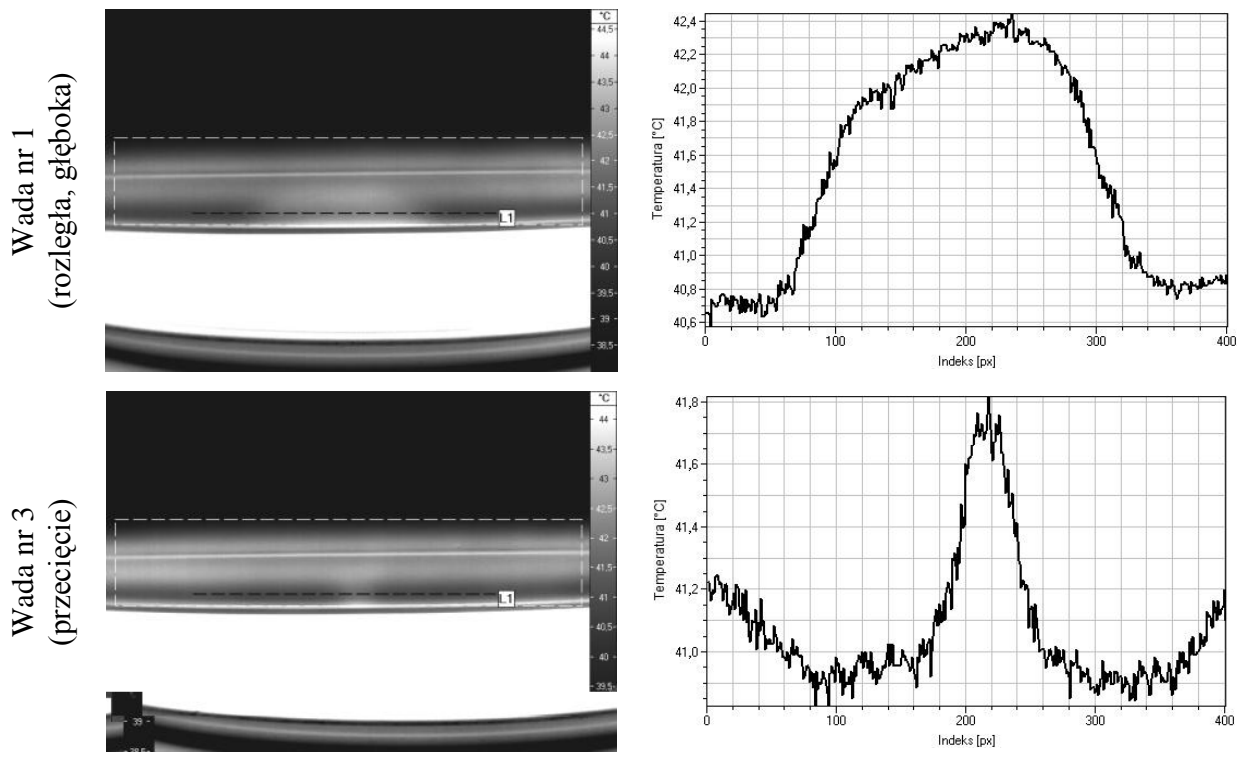

Rys. 8. Uzyskane przykładowe wyniki badań w warunkach laboratoryjnych (projekcja przednia) Fig. 8. Examples of results of laboratory investigations (front projection)

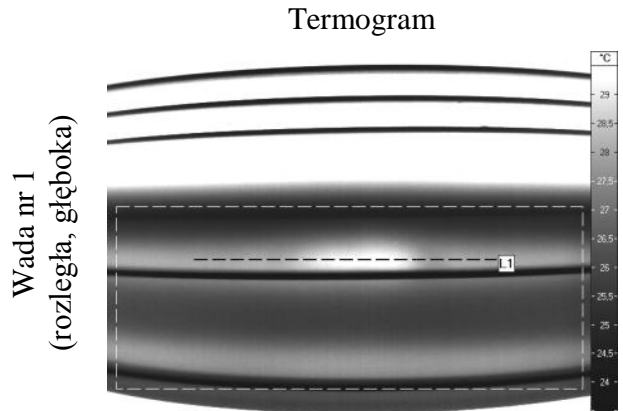

Wykres wzdłuż linii L1 na termogramie
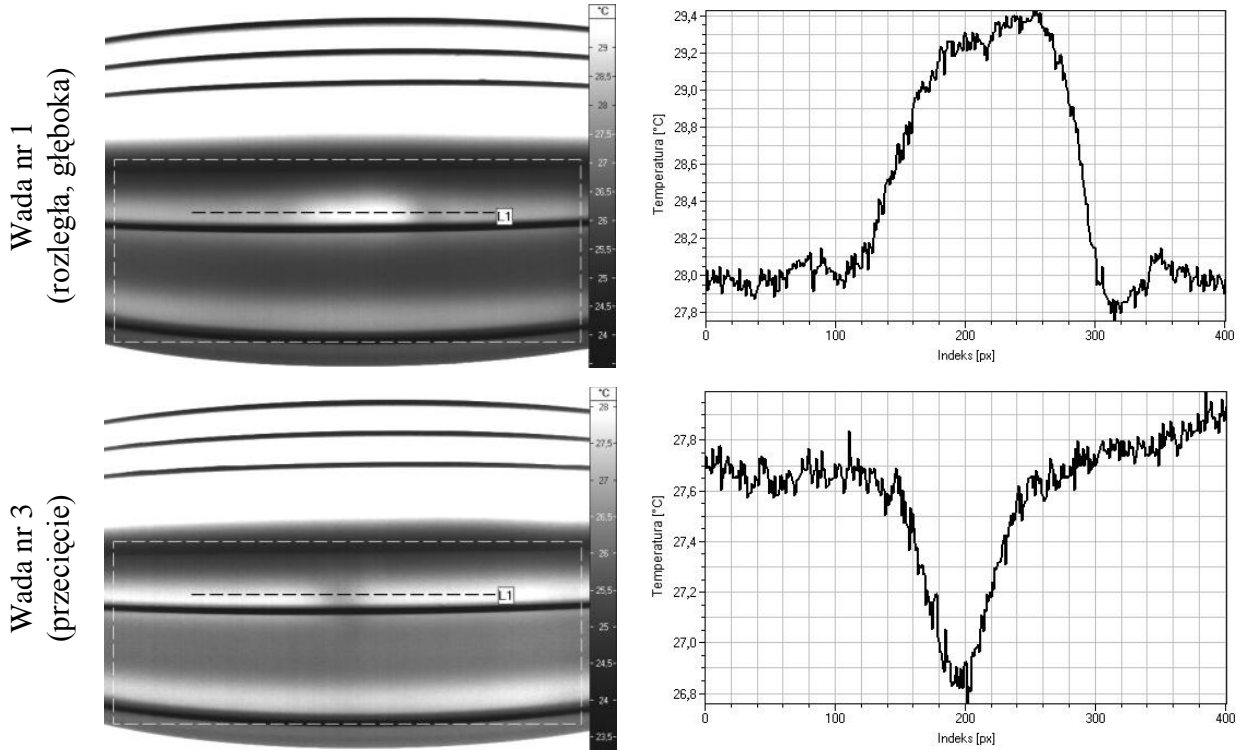

Rys. 9. Uzyskane przykładowe wyniki badań w warunkach laboratoryjnych (projekcja tylna)

Fig. 9. Examples of results of laboratory investigations (back projection) 
Odwrotnego efektu należy się spodziewać w przypadku projekcji tylnej (rys. 9.), tj. obecność defektów podpowierzchniowych powinna objawić się w tym przypadku w postaci obszarów o temperaturze obniżonej względem otaczającej powierzchni. Rzeczywiście efekt ten występuje w przypadku wady nr 3, jednak w odniesieniu do wady nr 1 jest on przeciwny do oczekiwanego, tj. występuje obszar o podwyższonej temperaturze względem otoczenia. Dzieje się tak dlatego, że wada nr 1 jest spowodowana uszkodzeniem o dużym rozmiarze i głębokości - na znacznym odcinku całkowicie usunięto materiał na powierzchni zewnętrznej rury, wskutek czego powierzchnia kielicha w tym obszarze jest bezpośrednio ogrzewana.

\section{Planowane dalsze badania}

Po wykonaniu badań wstępnych in situ oraz dokładniejszych analiz na półautomatycznym stanowisku badawczym, kolejnym etapem będzie ponowne przeprowadzenie badań $\mathrm{w}$ siedzibie producenta rur $\mathrm{z}$ wykorzystaniem odpowiednio przystosowanego stanowiska badawczego. Stanowisko wykorzystane w laboratorium zostało rozbudowane i wyposażone w dodatkową podpore pozwalającą na obrót rur o dowolnej długości (rys. 10.) oraz w automatykę do realizacji sprzężenia zwrotnego, które pozwoli na synchronizację rejestracji obrazów z obrotem rury. Dzięki tym modyfikacjom możliwe będzie utworzenie obrazu termicznego złącza w rozwinięciu w postaci tzw. widoku panoramicznego [9].

Istotnym celem do osiaggnięcia w następnym etapie jest zebranie dużej ilości materiału do wykonania statystyk i obserwacji zmienności parametrów poprawnie wykonywanych zgrzein w normalnym cyklu produkcyjnym. Ponadto planuje się określenie zmian obrazu termowizyjnego złącza rura-kielich w czasie. Badanie obejmą długoczasową rejestrację obrazów termowizyjnych wykonanych na kilku lub kilkunastu egzemplarzach produktu. Zebrane dane posłużą do opracowania algorytmów oraz oprogramowania, które pozwoli na automatyczną inspekcję połączeń rur $\mathrm{z}$ kielichami.

Rys. 10. Model stanowiska do obrotu rury o dowolnej długości z połączeniem kielichowym

Fig. 10. Stand model for turn of the pipe of any length with bell-shaped joint

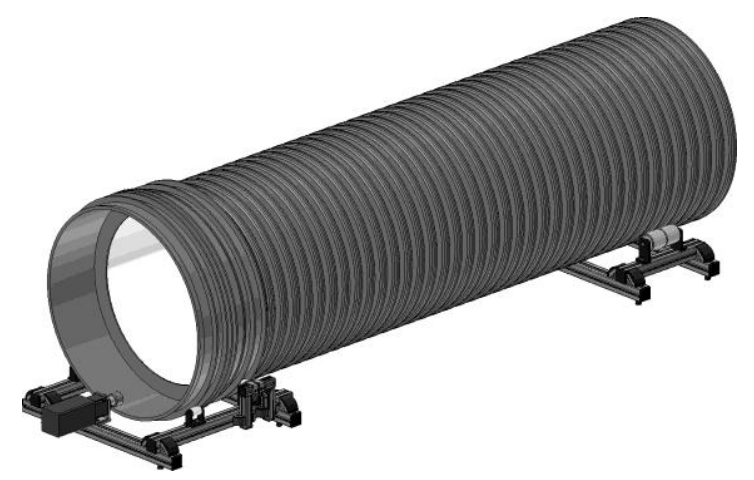




\section{Wnioski}

Przeprowadzone badania wykazały potencjalną możliwość zastosowania metod termograficznych do inspekcji połączeń rur z kielichami. Wykonane symulowane defekty w postaci ubytków, w formie pustej przestrzeni między rurą a kielichem, wykazują inne właściwości termiczne niż badany materiał. Pomiary potwierdziły przydatność zarówno metod termografii pasywnej, jak i termografii aktywnej, przy czym wyższy kontrast temperaturowy oraz większą liczbę wykrytych defektów zapewniają termogramy zarejestrowane w badaniach in situ z wykorzystaniem ciepła pochodzącego z procesu wytwarzania. Umożliwia to rezygnację z układu zewnętrznej stymulacji cieplnej badanych obiektów. Istnieje możliwość zastosowania opracowanej metody w praktyce przemysłowej, gdzie istotny jest brak potrzeby wstępnego przygotowania badanego obiektu do inspekcji wizyjnej oraz miejsce wykonania kontroli jakości, które nie powinny zaburzyć istniejącego procesu produkcyjnego. Równie istotny jest koszt wykonania stanowiska do inspekcji, który w przypadku metod korzystających z kamer termowizyjnych jest wysoki. Dalsze etapy prac wykażą, czy do realizacji tego zadania możliwe jest zastosowanie tańszej aparatury pomiarowej w postaci czujników punktowych. Opracowane stanowisko do precyzyjnego obrotu rury z kielichem zapewnia możliwość uzyskania powtarzalnych wyników pomiarowych i obserwację zmienności parametrów samego procesu zgrzewania tarciowego, przy jednoczesnej minimalizacji zakłóceń pomiarowych.

\section{Literatura}

1. Więcek B., De Mey G.: Termowizja w podczerwieni. Podstawy i zastosowania. Wydawnictwo PAK, Warszawa 2011.

2. Minkina W.: Pomiary termowizyjne - przyrządy i metody. Wydawnictwo Politechniki Częstochowskiej, Częstochowa 2004.

3. Oliferuk W.: Termografia podczerwieni w nieniszczących badaniach materiałów i urządzeń. Biuro Gamma, Warszawa 2008.

4. Szczepanik M., Stabik J., Wróbel G., Wierzbicki Ł.: Wykorzystanie systemów termowizyjnych do badań materiałów polimerowych. Modelowanie Inżynierskie, t. 5, z. 36, 2008 s. 279-286.

5. Czajka P., Giesko T., Mizak W.: Modelowanie procesu inspekcji materiałów w paśmie widzialnym i podczerwieni. Problemy Eksploatacji, nr 2/2012, s. 21-35.

6. Czajka P., Mizak W.: Modułowa struktura głowicy wizyjnej do hybrydowej kontroli jakości w paśmie widzialnym i podczerwieni. Technologia i Automatyzacja Montażu, nr 2(76), 2012, s. 42-47.

7. Projekt Badawczy Zamawiany PW-004/ITE/02/2004: „Budowa systemu pomiarowego do badań nieniszczących techniką termografii aktywnej”. Sprawozdanie końcowe, Centralny Instytut Ochrony Pracy - PIB, Warszawa 2005.

8. VarioCAM hr head User's Manual, InfraTec, http://www.infratec.de. 
9. Ahuja N., Barkan C.: Machine vision for railroad equipment undercarriage inspection using multi-spectral imaging. Final Report for High-Speed Rail IDEA Project 49, USA 2007.

Praca naukowa wykonana $w$ ramach realizacji Programu Strategicznego pn. „Innowacyjne systemy wspomagania technicznego zrównoważonego rozwoju gospodarki” w Programie Operacyjnym Innowacyjna Gospodarka.

\title{
THE USE OF THERMOVISUAL INSPECTION FOR ASSESSMENT OF CORRECTNESS OF ASSEMBLY OF PIPE COUPLERS
}

\begin{abstract}
The article presents the method for quality inspection of structural pipes, made of plastics, with couplers. The connection is made with the friction welding method. For the assessment of correctness of assembly of couplers the method of thermovision inspection is applied, which consists in analysis of the distribution of temperatures on the surface of the material. Before welding several faults were simulated by intentional damaging of the notches of the pipe. To test the sensitivity of the method four different faults were produced that differ in their area and depth. The experimental research was conducted in situ using the passive thermography and in the laboratory conditions using active thermography. In the method of passive thermography the thermal energy comes only from the object under test, without additional stimulation with external heat source. In such case the heat remaining after the pipe forming process is used as well as the heat generated during the welding process. In the method of active thermography the response of the material to the stimulation with external heat source is analysed. The main element of the inspection system is an infrared camera, equipped with non-cooled microbolometric sensor working in long-wave band of the infrared radiation. During tests the pipe was turned in relation to the IR camera to allow measurements of the weld along the whole circumference of the coupler. The variation of the temperature along selected profiles was observed on the recorded thermograms and analysed. To make the laboratory research possible, a special experimental test stand with electric motor was made, that allows precise rotation of the part of the pipe with welded coupler in relation to the infrared camera.
\end{abstract}

Keywords: passive and active thermography, defect detection, friction welding

DOI: $10.7862 / \mathrm{rm} .2013 .1$

Otrzymano/received: 25.02.2013

Zaakceptowano/accepted: 2.04 .2013 